\title{
Performance Evaluation and Path Analysis Studies in Tomato (Solanumlycopersiconl.) Genotpes under Humera, Northern Ethiopia Condition
}

\author{
Shushay Chernet ${ }^{1, *}$, Derbew Belew ${ }^{2}$, Fetien Abay ${ }^{3}$ \\ ${ }^{1}$ Humera Agricultural Research Center, Tigray Agricultural Research Institute, P.O. Box 62, Humera, Ethiopia \\ ${ }^{2}$ Jimma University College of Agriculture and Veterinary Medicine, P. O. Box 307, Jimma, Ethiopia \\ ${ }^{3}$ Department of Crop and Horticultural Sciences, Mekelle University, P.O. Box 231, Mekelle, Ethiopia \\ *Corresponding author: shishaychernet@yahoo.com
}

Received September 09, 2014; Revised September 28, 2014; Accepted November 12, 2014

\begin{abstract}
In order to evaluate performance of genotypes and study the direct and indirect effects of characters on fruit yield, thirty six tomato genotypes introduced from different countries were grown at Humera Agricultural Research Center during 2010/11 cropping season under irrigation condition. The trial was laid out in 6 x 6 simple lattice design in two replications. The maximum marketable yield was obtained from the genotype CLN-2037-A (49.20 tons ha ${ }^{-1}$ ) and the minimum with H-1350 (3.00 tons ha $\left.{ }^{-1}\right)$. Estimates of genotypic direct and indirect effects of various characters on fruit yield showed that number of matured fruits plant-1 (0.798) and average weight of fruits plant $^{-1}(0.644)$ had highest positive direct contribution to fruit yield. This indicated direct selection based on these characters will improve fruit yield. On the contrary, fruit set percentage (-0.447) and fruit polar diameter $(-0.392)$ exerted highest negative direct effect on fruit yield $\mathrm{ha}^{-1}$.
\end{abstract}

Keywords: tomato, genotypes, path analysis, direct effect, indirect effect

Cite This Article: Shushay Chernet, Derbew Belew, and Fetien Abay, "Performance Evaluation and Path Analysis Studies in Tomato (Solanumlycopersiconl.) Genotpes under Humera, Northern Ethiopia Condition.” World Journal of Agricultural Research, vol. 2, no. 6 (2014): 267-271. doi: 10.12691/wjar-2-6-3.

\section{Introduction}

Tomato (Solanumlycopersicon L.) is one of popular vegetables grown in the world. It requires warm and dry climate (MoARD, 2009). However, it is adapted to a wide range of climatic conditions from temperate to hot and humid tropics. The plant can survive a range of temperatures, but grow best under temperatures of 20$27^{\circ} \mathrm{C}$ (Naika et al., 2005).

In Ethiopia cultivation of tomato is increased in area coverage and volume of production from time to time. It showed an increment in total cultivated area from 5,342 ha with a production of 41,815 tons (FAOSTAT, 2011) to 7,237 ha with a volume of production 55,514 tons (FAOSTAT, 2012). This is because many domestic and foreign investors are attracted to the horticulture sector in Ethiopia. Moreover, the government contributing a lot to have farmers' alternative water source (exploit ground water or constructing common dams) besides, small scale farmers increased their awareness about the profitability of cultivation of vegetables and fruits through irrigation.

However, growing of tomato is constrained by many factors i.e. shortage of improved varieties, disease and pest infestation (Tutaabsoluta), poor agronomic practices and poor postharvest handling are some of the major production challenges.
Tomato fruit yield is a quantitative character, which is influenced by a number of yield contributing characters. Path coefficient analysis specifies the cause and measures the relative importance of the characters, while correlation measures only mutual association without considering causation (Dewey and Lu, 1959). Moreover, path coefficient analysis partitions the genotypic correlation into direct and indirect effects via alternative characters and assists plant breeders in identifying traits that are useful as selection criteria to improve crop yield (Dewey and Lu, 1959; Samonte et al., 1998).

Many authors Hidayatullah et al. (2008); Mehta and Asati (2008); Ghosh et al. (2010); Tiwari and Upadhyay, 2011; Tanuja et al. (2012); Reddy et al. (2013) have been made study on path coefficient analysis and evaluation studies in tomato. However, little information is available with respect to path coefficient analysis studies on tomato genotypes under Ethiopian conditions. Therefore, a study was carried out to evaluate performance of genotypes and study the direct and indirect effect of characters on fruit yield.

\section{Materials and Methods}

Thirty sixtomato genotypes introduced from different sources i.e. Asian Vegetable Research and Development Center (AVRDC) (17), Israel (4), Italy (7) USA (1), 
Guadaloupe (1), France (1) and information not available (5) were grown in Humera Agricultural research Center experimental site during 2010/11 under irrigation condition. Humera is located $14^{\circ} 06^{\prime} \mathrm{N}$ latitude and $38^{\circ} 31^{\prime}$ E longitude at an altitude of 604 meter above sea level. The maximum temperature varies from $33^{\circ} \mathrm{C}$ to $42^{\circ} \mathrm{C}$ and the minimum $17.5^{\circ} \mathrm{C}$ to $22.2^{\circ} \mathrm{C}$ (EARO, 2002). The experiment was laid out in 6 x 6 simple lattice design in two replications. The trial had gross plot size of $4 \mathrm{~m} * 5.1$ m with a net plot size of 2 x $5.1 \mathrm{~m}$ spaced at 100x30 cm between rows and plants respectively. DAP @ $200 \mathrm{~kg} \mathrm{ha}^{-1}$ and Urea@100 kg ha ${ }^{-1}$ were applied at time of planting and two weeks after transplanting as of recommended for the crop (Lemma, 2002).

Ten plants and 10 fruits were randomly sampled from middle two rows leaving the two rows as borders. Data's on plant height $(\mathrm{cm})$, primary branches, number of flowers plant $^{-1}$, number of fruit clusters plant ${ }^{-1}$, number of fruits cluster $^{-1}$, number of fruits plant ${ }^{-1}$, fruit set percentage (\%), weight of fruit plant ${ }^{-1}(\mathrm{~kg})$, single fruit weight $(\mathrm{g})$, fruit polar diameter $(\mathrm{mm})$, equatorial diameter $(\mathrm{mm})$, Fruit shape index, number of locules fruit ${ }^{-1}$, Pericarp thickness (mm), number of seeds fruit ${ }^{-1}$ and total soluble solids (TSS) ( ${ }^{\circ}$ Brix) were recorded per plant and fruit basis. Measurements such as days to $50 \%$ flowering, days to maturity, number of Pickings and fruit yield ha ${ }^{-1}(\mathrm{t})$ were taken on plot basis.

Statistical analysis were done according to Montogomery (2005) using statistical analysis software (SAS) package and treatment means were compared using least significant difference (LSD) at 1\% probability level. Path coefficient analysis was computed according the method given by Dewey and Lu (1959) using the genotypic correlation coefficients to determine the direct and indirect effects of yield components on fruit yield (tons ha-1).

Table 1. Growth and yield components of tomato genotypes grown in Humera

\begin{tabular}{|c|c|c|c|c|c|c|c|c|c|c|c|}
\hline No & Name of genotype & 50FL & DM & PHT (cm) & PBR & NFLO & NFCL & FRPC & FRPP & FSPER (\%) & WFPP (kg) \\
\hline 1 & Fetan & 40 & 132 & 68.9 & 9.2 & 123 & 3.87 & 1.14 & 15 & 12.4 & 0.504 \\
\hline 2 & 5915-206-d4-2-2-0 & 52 & 103 & 102.8 & 5.8 & 127 & 7.50 & 1.60 & 30 & 23.9 & 1.400 \\
\hline 3 & Beaf steak & 55 & 153 & 71.8 & 6.2 & 49 & 3.45 & 1.28 & 6 & 13.0 & 0.392 \\
\hline 4 & CLN-2037-H & 46 & 105 & 120.1 & 6.4 & 91 & 10.20 & 1.82 & 42 & 45.6 & 1.020 \\
\hline 5 & CLN-2366-C & 40 & 93 & 88.2 & 1.8 & 91 & 9.35 & 1.40 & 31 & 33.8 & 0.409 \\
\hline 6 & Chali & 37 & 99 & 62.3 & 7.3 & 117 & 7.59 & 1.65 & 32 & 27.8 & 0.660 \\
\hline 7 & CLN-2498 & 41 & 107 & 120.2 & 7.7 & 186 & 1.72 & 1.00 & 7 & 3.58 & 0.125 \\
\hline 8 & CLN-2037-C & 35 & 106 & 120.8 & 8.4 & 184 & 4.50 & 1.20 & 31 & 16.8 & 1.219 \\
\hline 9 & Miya & 30 & 79 & 67.1 & 6.8 & 91 & 10.75 & 2.15 & 42 & 46.0 & 1.633 \\
\hline 10 & Roma-VF & 38 & 120 & 73.1 & 6.9 & 130 & 7.26 & 1.56 & 25 & 18.9 & 0.665 \\
\hline 11 & CLN-2037-A & 30 & 79 & 106.1 & 6.4 & 116. & 15.25 & 2.36 & 94 & 80.5 & 1.717 \\
\hline 12 & PT-4719B & 36 & 80 & 92.5 & 5.8 & 100 & 13.88 & 2.25 & 59 & 59.3 & 1.168 \\
\hline 13 & Fire ball & 35 & 100 & 60.5 & 5.0 & 91 & 8.59 & 1.38 & 28 & 31.5 & 1.119 \\
\hline 14 & Supper Roma-VF & 37 & 105 & 72.1 & 7.1 & 158 & 10.25 & 1.86 & 29 & 18.3 & 0.933 \\
\hline 15 & CLN-2037-E & 42 & 90 & 117.8 & 8.7 & 135 & 5.09 & 1.41 & 25 & 18.1 & 1.198 \\
\hline 16 & Bishola & 42 & 112 & 101.8 & 6.6 & 119 & 5.02 & 1.88 & 10 & 8.5 & 0.591 \\
\hline 17 & CLN-2037-I & 38 & 96 & 102.5 & 4.4 & 86 & 5.50 & 1.72 & 28 & 33.1 & 1.024 \\
\hline 18 & Tomato $1358 / 95$ & 45 & 154 & 61.5 & 5.5 & 38 & 1.0 & 0.75 & 3 & 9.2 & 0.249 \\
\hline 19 & CLN-1621-F & 38 & 83 & 91.2 & 5.3 & 64 & 7.58 & 1.63 & 51 & 82.9 & 1.616 \\
\hline 20 & Eshet & 42 & 99 & 129.0 & 6.5 & 118 & 8.29 & 1.59 & 24 & 20.3 & 0.720 \\
\hline 21 & Marglobe & 43 & 93 & 67.1 & 5.7 & 93 & 6.40 & 1.86 & 22 & 24.3 & 0.565 \\
\hline 22 & CL 5915-93-D4 & 28 & 69 & 59.5 & 6.1 & 126 & 18.08 & 4.55 & 97 & 77.0 & 2.10 \\
\hline 23 & 5915-206-d4-2-5-0 & 37 & 82 & 112.9 & 6.1 & 93 & 9.82 & 2.34 & 31 & 34.2 & 1.447 \\
\hline 24 & Metadel & 36 & 149 & 59.0 & 6.2 & 40 & 1.65 & 1.35 & 6 & 14.8 & 0.380 \\
\hline 25 & ARP Tomato No 367-2 & 41 & 153 & 108.5 & 6.2 & 64 & 3.50 & 1.60 & 8 & 12.7 & 0.465 \\
\hline 26 & Cathrine & 50 & 156 & 116.5 & 8.1 & 99 & 1.75 & 1.05 & 5 & 5.1 & 0.325 \\
\hline 27 & Tomato $1365 / 95$ & 34 & 78 & 72.3 & 6.4 & 80 & 19.40 & 1.78 & 22 & 28.2 & 1.426 \\
\hline 28 & Electra & 38 & 97 & 106.6 & 6.4 & 86 & 5.02 & 1.47 & 18 & 21.3 & 1.292 \\
\hline 29 & CLN-13114-G & 44 & 141 & 126.4 & 6.9 & 92 & 1.74 & 1.55 & 7 & 7.2 & 0.539 \\
\hline 30 & $\mathrm{H}-1350$ & 51 & 155 & 93.0 & 5.4 & 44 & 3.95 & 1.30 & 8 & 17.4 & 0.374 \\
\hline 31 & Cochora & 34 & 81 & 73.7 & 6.0 & 109 & 14.17 & 2.27 & 36 & 33.0 & 0.870 \\
\hline 32 & CLN-2366-A & 38 & 82 & 84.5 & 6.3 & 111 & 6.05 & 1.60 & 14 & 12.3 & 0.605 \\
\hline 33 & Melka salsa & 35 & 90 & 87.3 & 7.0 & 106 & 9.49 & 2.01 & 19 & 18.0 & 0.783 \\
\hline 35 & CLN-2070-A & 31 & 77 & 108.8 & 7.8 & 120 & 15.42 & 2.84 & 55 & 47.5 & 1.090 \\
\hline 36 & Melka Shola & 33 & 78 & 94.4 & 6.2 & 112 & 10.33 & 1.59 & 24 & 21.8 & 0.650 \\
\hline & Mean & 39 & 104 & 91.07 & 6.40 & 103 & 7.80 & 1.71 & 28 & 27.6 & 0.887 \\
\hline & $\operatorname{SEM}( \pm)$ & 0.220 & 0.440 & 0.570 & 0.080 & 0.870 & 0.112 & 0.021 & 0.218 & 0.303 & 0.012 \\
\hline & CV (\%) & 7.27 & 5.53 & 8.21 & 15.87 & 10.99 & 18.73 & 16.45 & 10.22 & 14.36 & 17.50 \\
\hline & LSD at $1 \%$ & 7.27 & 14.92 & 18.19 & 2.83 & 31.61 & 4.15 & 0.78 & 7.97 & 10.48 & 0.443 \\
\hline & Significant level & ** & ** & ** & $* *$ & $* *$ & $* *$ & $* *$ & ** & ** & $* *$ \\
\hline
\end{tabular}

$50 \mathrm{FL}=$ days to 50 percent flowering, $\mathrm{DM}=$ days to maturity, $\mathrm{PHT}=$ plant height, $\mathrm{PBR}=$ number of primary branches, $\mathrm{NFLO}=$ number of flowers per plant, NFCL= number of fruit clusters per plant, FRPC= number of fruits per fruit cluster, FRPP= number of matured fruits per plant, FSPE= fruit set percentage, WFPP= average weight of fruits per plant, $\mathrm{SEM}=$ standard of the mean, $\mathrm{CV}=$ coefficient of variation and LSD= least significant difference and $* *=$ highly significant difference 
Table 2. fruit characteristic and yield of tomato genotypes grown in Humera

\begin{tabular}{|c|c|c|c|c|c|c|c|c|c|c|c|}
\hline No & Name of genotype & SFW(g) & NPIC & $\begin{array}{l}\text { FPD } \\
(\mathrm{mm})\end{array}$ & $\begin{array}{l}\text { FED } \\
(\mathrm{mm})\end{array}$ & SHIN & NSEE & NLOC & $\begin{array}{l}\text { PETI } \\
(\mathrm{mm})\end{array}$ & $\begin{array}{c}\text { TSS } \\
\left({ }^{\circ} \text { Brix }\right)\end{array}$ & $\begin{array}{l}\text { MYLD } \\
\text { (t/ha) }\end{array}$ \\
\hline 1 & FETAN & 73 & 3.0 & 49.2 & 47.6 & 1.03 & 38 & 3.95 & 6.65 & 5.42 & 8.49 \\
\hline 2 & 5915-206-D4-2-2-0 & 60 & 5.0 & 42.9 & 45.8 & 0.94 & 40 & 4.50 & 4.33 & 4.83 & 25.67 \\
\hline 3 & Beaf steak & 95 & 3.0 & 41.5 & 40.2 & 1.03 & 15 & 3.00 & 5.03 & 4.50 & 5.35 \\
\hline 4 & CLN-2037-H & 30 & 4.5 & 36.3 & 39.0 & 0.93 & 17 & 4.45 & 3.37 & 4.98 & 18.94 \\
\hline 5 & CLN-2366-C & 18 & 4.0 & 36.1 & 27.5 & 1.32 & 32 & 2.47 & 3.17 & 6.12 & 13.18 \\
\hline 6 & Chali & 49 & 4.0 & 54.3 & 44.8 & 1.21 & 37 & 3.65 & 5.93 & 3.78 & 12.76 \\
\hline 7 & CLN-2498 & 43 & 4.0 & 57.9 & 35.8 & 1.62 & 28 & 2.55 & 5.15 & 4.52 & 5.89 \\
\hline 8 & CLN-2037-C & 60 & 4.5 & 41.5 & 45.0 & 0.92 & 68 & 3.25 & 4.83 & 5.64 & 15.96 \\
\hline 9 & Miya & 67 & 5.0 & 52.0 & 47.0 & 1.11 & 30 & 2.50 & 7.48 & 4.83 & 35.28 \\
\hline 10 & Roma-VF & 57 & 4.0 & 60.6 & 34.2 & 1.92 & 60 & 2.60 & 5.70 & 5.26 & 20.74 \\
\hline 11 & CLN-2037-A & 26 & 5.0 & 34.2 & 36.7 & 0.93 & 45 & 5.00 & 3.03 & 6.71 & 49.20 \\
\hline 12 & PT-4719B & 42 & 5.0 & 37.1 & 39.0 & 0.95 & 78 & 2.75 & 4.75 & 5.39 & 28.65 \\
\hline 13 & Fire ball & 54 & 4.5 & 50.1 & 43.6 & 1.15 & 23 & 3.00 & 6.35 & 3.80 & 19.06 \\
\hline 14 & Supper Roma-VF & 46 & 4.5 & 60.6 & 33.1 & 1.83 & 38 & 2.00 & 5.38 & 5.38 & 17.47 \\
\hline 15 & CLN-2037-E & 62 & 4.5 & 46.2 & 42.1 & 1.11 & 51 & 3.25 & 5.10 & 4.79 & 20.13 \\
\hline 16 & Bishola & 147 & 3.0 & 41.1 & 50.7 & 0.81 & 43 & 2.95 & 4.81 & 4.93 & 5.58 \\
\hline 17 & CLN-2037-I & 46 & 5.0 & 42.0 & 41.2 & 1.02 & 44 & 3.50 & 4.05 & 5.81 & 19.00 \\
\hline 18 & Tomato 1358/95 & 40 & 2.5 & 34.0 & 33.8 & 1.01 & 31 & 2.75 & 2.55 & 5.63 & 3.02 \\
\hline 19 & CLN-1621-F & 69 & 5.0 & 46.5 & 44.5 & 1.05 & 35 & 3.75 & 4.65 & 4.70 & 22.81 \\
\hline 20 & Eshet & 29 & 4.0 & 40.9 & 37.9 & 1.08 & 40 & 2.75 & 4.08 & 5.37 & 9.77 \\
\hline 21 & Marglobe & 58 & 4.5 & 37.2 & 40.0 & 0.96 & 51 & 4.25 & 4.28 & 5.28 & 15.78 \\
\hline 22 & CLN 5915-93-D4 & 31 & 6.0 & 39.3 & 36.3 & 1.08 & 64 & 2.50 & 4.95 & 5.45 & 43.27 \\
\hline 23 & 5915-206-d4-2-5-0 & 75 & 5.0 & 49.6 & 46.6 & 1.07 & 33 & 3.90 & 4.06 & 4.88 & 26.78 \\
\hline 24 & Metadel & 58 & 2.5 & 38.0 & 36.8 & 1.03 & 30 & 2.85 & 3.15 & 5.46 & 3.01 \\
\hline 25 & $\begin{array}{c}\text { ARP Tomato No 367- } \\
2\end{array}$ & 77 & 3.0 & 44.1 & 52.3 & 0.85 & 53 & 5.00 & 5.65 & 5.05 & 4.84 \\
\hline 26 & Cathrine & 58 & 2.0 & 41.4 & 39.6 & 1.05 & 102 & 2.95 & 2.75 & 5.68 & 3.14 \\
\hline 27 & Tomato 1365/95 & 106 & 5.0 & 46.6 & 64.4 & 0.73 & 94 & 6.05 & 5.15 & 5.56 & 25.82 \\
\hline 28 & Electra & 76 & 3.5 & 55.6 & 41.8 & 1.33 & 103 & 5.25 & 5.75 & 5.53 & 14.67 \\
\hline 29 & CLN-13114-G & 45 & 3.5 & 46.2 & 38.3 & 1.21 & 39 & 4.55 & 3.49 & 5.75 & 4.85 \\
\hline 30 & H-1350 & 26 & 2.0 & 40.5 & 31.0 & 1.31 & 44 & 2.00 & 3.47 & 3.58 & 3.00 \\
\hline 31 & Cochora & 36 & 5.0 & 54.1 & 37.1 & 1.48 & 32 & 1.95 & 6.85 & 5.10 & 18.00 \\
\hline 32 & CLN-2366-A & 41 & 3.5 & 38.8 & 35.2 & 1.10 & 35 & 2.60 & 3.15 & 5.81 & 8.45 \\
\hline 33 & Melka salsa & 56 & 4.5 & 59.0 & 38.3 & 1.54 & 46 & 2.60 & 5.65 & 4.68 & 16.90 \\
\hline 34 & CLN-2366-B & 45 & 5.0 & 44.3 & 41.6 & 1.07 & 50 & 2.75 & 5.05 & 5.72 & 13.02 \\
\hline 35 & CLN-2070-A & 34 & 5.0 & 38.8 & 39.1 & 0.99 & 124 & 4.25 & 3.65 & 5.75 & 16.25 \\
\hline \multirow[t]{6}{*}{36} & Melka Shola & 40 & 5.5 & 58.6 & 39.9 & 1.47 & 37 & 2.75 & 5.73 & 4.70 & 10.67 \\
\hline & Mean & 55 & 4.15 & 45.6 & 40.8 & 1.14 & 48 & 3.36 & 4.70 & 5.18 & 16.26 \\
\hline & $\operatorname{SEM}( \pm)$ & 0.587 & 0.034 & 0.180 & 0.196 & 0.007 & 0.274 & 0.018 & 0.043 & 0.009 & 1.930 \\
\hline & CV (\%) & 13.96 & 10.68 & 5.16 & 6.27 & 7.49 & 7.47 & 6.80 & 12.06 & 2.34 & 14.98 \\
\hline & LSD at $1 \%$ & 20.437 & 1.24 & 6.31 & 7.48 & 0.246 & 10.43 & 0.66 & 1.49 & 0.32 & 6.64 \\
\hline & Significant level & $* *$ & $* *$ & $* *$ & $* *$ & $* *$ & $* *$ & $* *$ & $* *$ & $* *$ & $* *$ \\
\hline
\end{tabular}

$\mathrm{SFW}=$ single fruit weight per plant, FPD= fruit polar diameter, $\mathrm{FED}=$ fruit equatorial diameter, SHIN= shape index, NPIC= number of fruit pickings, $\mathrm{NSEE}=$ number of seeds per fruit, NLOC= number of locules per fruit, $\mathrm{PETI}=$ pericarp thickness, TSS= total soluble solids, MYLD=marketable yield per hectare SEM=standard of the mean, $\mathrm{CV}=$ coefficient of variation and LSD= least significant difference and **= highly significant difference

\section{Results and Discussion}

All the 36 tomato genotypes studied showed highly significant differences $(p<0.01)$ for all the characters studied (Table 1). Days to 50\% flowering ranged from 28 to 55 with a mean of 39 days. Similarly Ghosh et al., 2010 reported a wide range of variation for days to initial flowering in tomato. Days to maturity ranged from 69 to 156 days. CLN 5915-93-D4 genotype, the second high yielder genotype, was the earliest to mature (69 days) whereas Cathrine was the late matured (156 days). This is in line with the finding of Meseret et al., 2012 who reported a wide range of difference in days to first harvest (70 to 120 days) in tomato varieties evaluated in Jimma.

A wide range of difference was observed for plant height (59 to $129 \mathrm{~cm}$ ). Similarly Meseret et al. (2012) reported a wide range of difference in tomato varieties (40.2 to $107 \mathrm{~cm}$ ). Pradeepkumar et al. (2001) also found a wide range of differences in plant height. Total number of matured fruits plant ${ }^{-1}$ ranged from 4 to 96 with an average of 28 fruits plant $^{-1}$. This is in agreement with the finding of Muhamed et al., 2013 who reported a wide range of difference in number of fruits plant ${ }^{-1}$ (11-85) and Jiregna,
2013 (8 to 59 fruits plant ${ }^{-1}$ ). Similarly, Pradeepkumar et al. (2001) obtained a wide range of variation for number of fruits plant ${ }^{-1}$. The maximum number of fruits was scored by CLN 5915-93-D4 genotype (96) while tomato- 1358 scored the least number of matured fruits plant ${ }^{-1}(4)$.

Average weight of fruits plant ${ }^{-1}$ ranged from 0.13 to $2.10 \mathrm{~kg}$ with an average weight of $0.887 \mathrm{~kg}$. Similarly, Jiregna (2013) (0.22 - $1.61 \mathrm{~kg}$ plant $\left.^{-1}\right)$ and Muhamed et al., $2013(0.25-2.48 \mathrm{~kg})$ found a wide range of difference. The highest yield plant ${ }^{-1}$ were recorded by CLN 5915-93-D4 genotype $(2.102 \mathrm{~kg})$ and CLN-2037-A (1.716 kg). Single fruit weight ranged from 18 to 147 gram. This is in agreement with the finding of Muhamed et al. (2013) who reported a wide range of difference (6.18 -74.91 gram). Similarly, Pradeepkumar et al. (2001), reported wide range of variability for single fruit weight.

Total fruit yield per hectare ranged from 3.00 to 49.20 tons $\mathrm{ha}^{-1}$ which showed wide difference with a mean of 16.26 tons $\mathrm{ha}^{-1}$. The maximum yield was obtained from CLN-2037-A (49.20 tons ha $^{-1}$ ) followed by CLN 5915-93D4 (43.27 tons ha ${ }^{-1}$ ) and Miya (35.28 tons ha ${ }^{-1}$ ).Generally, the genotypes which scored the highest number of fruits and fruit yield per plant had the highest fruit yield per hectare (Table 2). 
Fruit polar and equatorial diameter ranged from 34.0 to $65.3 \mathrm{~mm}$ and 27.5 to $64.4 \mathrm{~mm}$. This is in line with the finding of Syed et al. (2001) who reported wide range in fruit width and length $(3.2-5.2 \mathrm{~cm})$ and $(5.6-8.5 \mathrm{~cm})$. Number of locules per fruit ranged from 2 to 5. Pericarp thickness varied from 2.55 to $7.48 \mathrm{~mm}$. Number of seeds per fruit ranged from 18 to 118 with an average of 48 and total soluble solids (TSS) varied from 3.33 to $6.71{ }^{\circ}$ Brix (Table 2). Similar results on pericarp thickness, TSS, and number of locules were also reported by Shashikanth et al. (2010).

Path coefficient analysis involves partitioning of the correlation coefficients into direct and indirect effects via alternative characters. Fruit yield is the final products of various characters and here it was considered to be the resultant variable while the rest of the variables were casual variables. Each character influence fruit yield by its direct and indirect contributions with other characters. An aggregate residual factor that includes all other factors affecting fruit yield and not yet accounted for was treated as independent of the rest of factors considered. The residual factor 0.235 (Table 3.) implied that characters included in the path analysis explained $76.5 \%$ of the total variation in fruit yield per hectare while the remaining $23.5 \%$ was contributed by other factors not included in the path analysis.

Table 3. Path coefficients of direct (main diagonal) and indirect effects of the characters studied

\begin{tabular}{|c|c|c|c|c|c|c|c|c|c|c|}
\hline & $50 \mathrm{FL}$ & DM & PHT & PBR & NFLO & NFCL & FRPC & FRPP & FSPE & WFPP \\
\hline 50FL & 0.066 & 0.022 & 0.009 & 0.001 & 0.046 & -0.089 & 0.120 & -0.477 & 0.227 & -0.348 \\
\hline DM & $\begin{array}{l}0.049 \\
\end{array}$ & \begin{tabular}{|l|}
0.030 \\
\end{tabular} & $\begin{array}{l}0.001 \\
\end{array}$ & $\begin{array}{l}-0.001 \\
\end{array}$ & $\begin{array}{l}0.061 \\
\end{array}$ & -0.103 & $\begin{array}{l}0.120 \\
\end{array}$ & -0.528 & 0.268 & -0.441 \\
\hline PHT & 0.019 & 0.001 & 0.030 & -0.002 & -0.042 & -0.026 & 0.024 & -0.045 & 0.042 & -0.002 \\
\hline PBR & -0.005 & 0.003 & 0.008 & -0.008 & -0.082 & -0.024 & 0.031 & -0.094 & 0.137 & 0.001 \\
\hline NFLO & -0.021 & -0.013 & 0.009 & -0.005 & -0.142 & 0.020 & -0.029 & 0.182 & 0.015 & 0.104 \\
\hline NFCL & -0.045 & -0.024 & -0.006 & 0.001 & -0.022 & \begin{tabular}{|l|l|}
0.131 \\
\end{tabular} & -0.160 & 0.621 & -0.325 & 0.453 \\
\hline FRPC & -0.038 & -0.017 & -0.004 & 0.001 & -0.020 & 0.102 & -0.208 & 0.647 & -0.318 & 0.442 \\
\hline FRPP & -0.040 & -0.020 & -0.002 & 0.001 & -0.032 & 0.102 & -0.169 & 0.798 & -0.416 & 0.521 \\
\hline FSPE & -0.034 & -0.018 & -0.003 & 0.002 & 0.005 & 0.096 & -0.148 & 0.744 & $\begin{array}{l}-0.447 \\
\end{array}$ & 0.512 \\
\hline WFPP & -0.036 & -0.021 & 0.000 & 0.000 & -0.023 & 0.093 & -0.143 & 0.646 & -0.355 & $\begin{array}{l}0.644 \\
\end{array}$ \\
\hline SFW & 0.011 & 0.005 & -0.002 & -0.003 & 0.016 & -0.023 & 0.031 & -0.284 & 0.126 & 0.011 \\
\hline FPD & -0.017 & -0.004 & -0.004 & 0.003 & -0.053 & 0.002 & 0.017 & -0.160 & 0.111 & -0.013 \\
\hline FED & -0.008 & -0.004 & 0.000 & -0.003 & 0.008 & 0.023 & -0.004 & -0.061 & 0.004 & 0.219 \\
\hline SHIN & -0.008 & -0.001 & -0.004 & -0.001 & -0.050 & -0.007 & 0.018 & -0.110 & 0.100 & -0.162 \\
\hline NPIC & -0.044 & -0.027 & 0.000 & 0.000 & -0.064 & 0.105 & -0.133 & 0.590 & -0.297 & 0.493 \\
\hline NSEE & -0.015 & -0.005 & 0.007 & -0.003 & -0.020 & 0.037 & -0.052 & 0.134 & -0.041 & 0.153 \\
\hline NLOC & 0.003 & -0.002 & 0.008 & -0.001 & 0.023 & 0.021 & -0.010 & 0.087 & -0.073 & 0.209 \\
\hline PETI & -0.025 & -0.009 & -0.012 & -0.003 & -0.042 & 0.027 & -0.025 & 0.029 & 0.001 & 0.142 \\
\hline TSS & -0.019 & -0.005 & 0.005 & $\begin{array}{l}0.001 \\
\end{array}$ & -0.017 & 0.023 & -0.028 & 0.207 & -0.072 & 0.085 \\
\hline & SFW & FPD & FED & SHIN & NPIC & NSEE & NLOC & PETI & TSS & $r_{g}$ \\
\hline 50FL & 0.019 & 0.098 & -0.016 & -0.064 & 0.003 & 0.037 & 0.004 & -0.039 & -0.019 & $-0.581^{* *}$ \\
\hline DM & 0.018 & 0.058 & -0.020 & -0.010 & 0.004 & 0.026 & -0.005 & -0.030 & -0.010 & $-0.710^{* *}$ \\
\hline PHT & -0.007 & 0.050 & 0.000 & -0.066 & 0.000 & -0.038 & 0.025 & -0.041 & 0.012 & -0.110 \\
\hline PBR & 0.037 & -0.160 & 0.046 & 0.039 & 0.000 & -0.061 & 0.010 & 0.032 & -0.007 & -0.093 \\
\hline NFLO & -0.013 & -0.147 & -0.008 & 0.195 & -0.002 & -0.023 & -0.014 & 0.030 & 0.008 & 0.218 \\
\hline NFCL & -0.019 & -0.005 & 0.024 & -0.029 & $\begin{array}{l}-0.004 \\
\end{array}$ & -0.047 & 0.014 & 0.021 & 0.012 & $0.785^{* *}$ \\
\hline FRPC & -0.017 & 0.033 & 0.003 & -0.048 & -0.003 & -0.041 & 0.004 & 0.012 & 0.009 & $0.703^{* *}$ \\
\hline FRPP & -0.040 & 0.078 & -0.010 & -0.076 & -0.003 & -0.028 & 0.010 & 0.004 & 0.017 & 0.870** \\
\hline FSPE & -0.032 & 0.097 & -0.001 & -0.123 & -0.003 & -0.015 & 0.015 & 0.000 & 0.011 & $0.814 * *$ \\
\hline WFPP & 0.002 & 0.008 & 0.047 & -0.138 & -0.004 & -0.039 & 0.029 & 0.022 & 0.009 & $0.910 * *$ \\
\hline SFW & 0.112 & -0.056 & 0.104 & -0.180 & 0.001 & -0.016 & 0.028 & 0.038 & -0.012 & -0.127 \\
\hline FPD & 0.016 & -0.392 & 0.010 & 0.428 & -0.001 & 0.009 & -0.017 & 0.076 & -0.027 & -0.003 \\
\hline FED & 0.085 & -0.029 & 0.137 & -0.300 & -0.001 & -0.036 & 0.056 & 0.043 & -0.010 & 0.163 \\
\hline SHIN & -0.037 & -0.305 & -0.075 & 0.549 & 0.000 & 0.026 & -0.048 & 0.034 & -0.014 & -0.103 \\
\hline NPIC & -0.025 & -0.074 & 0.027 & 0.013 & -0.005 & -0.010 & 0.010 & 0.037 & 0.008 & $0.803^{* *}$ \\
\hline NSEE & 0.011 & 0.022 & 0.030 & $\begin{array}{l}-0.087 \\
\end{array}$ & 0.000 & -0.165 & 0.032 & -0.009 & 0.024 & 0.114 \\
\hline NLOC & 0.035 & 0.072 & 0.086 & -0.296 & -0.001 & -0.059 & 0.089 & -0.010 & 0.017 & 0.216 \\
\hline PETI & 0.042 & -0.297 & 0.058 & 0.185 & -0.002 & 0.015 & -0.009 & 0.101 & -0.031 & 0.206 \\
\hline TSS & -0.020 & 0.157 & -0.020 & -0.113 & -0.001 & -0.060 & 0.022 & -0.046 & 0.067 & 0.211 \\
\hline
\end{tabular}

Residual effect $=0.235 *$ and $* *$ indicate significance at 0.05 and 0.01 probability levels, respectively. 50FL $=$ days to 50 percent flowering, $\mathrm{DM}=$ days to maturity, $\mathrm{PHT}=$ plant height, $\mathrm{PBR}=$ number of primary branches, $\mathrm{NFLO}=$ number of flowers per plant, NFCL= number of fruit clusters per plant, FRPC = number of fruits per fruit cluster, FRPP= number of matured fruits per plant, FSPE= fruit set percentage, WFPP= average weight of fruits per plant, $\mathrm{SFW}=$ average single fruit weight per plant, $\mathrm{FPD}=$ fruit polar diameter, $\mathrm{FED}=$ fruit equatorial diameter, $\mathrm{SHIN}=$ shape index, NPICK= number of fruit pickings, NSEE= number of seeds per fruit, NLOC= number of locules per fruit, PETI= pericarp thickness, TSS $=$ total soluble solids, and $r_{\mathrm{g}}=$ genotypic coefficient of correlation

Estimates of direct and indirect effects of various characters on fruit yield tons $\mathrm{ha}^{-1}$ are indicated in Table 3. Number of matured fruits plant ${ }^{-1}$ had the highest direct positive contribution to fruit yield tons $\mathrm{ha}^{-1}(0.798)$ followed by weight of fruits plant ${ }^{-1}(0.644)$ and shape index (0.549) indicating that direct selection based on these characters will improve the total fruit yield at this particular location for the particular crop. Similarly, Islam et al. (2010) reported number of fruits plant ${ }^{-1}$ had highest (0.980) positive direct effect on fruit yield plant ${ }^{-1}$ in 39 tomato genotypes studied in Bangladesh.
Characters that had negative direct effects for total fruit yield ha ${ }^{-1}$ (Table 3 ) were fruit set percentage $(-0.447)$, fruit polar diameter $(-0.392)$ and number of fruits cluster ${ }^{-1}$ ($0.208)$. However, the negative direct effect of fruit set percentage (-0.447) was compensated by its indirect positive effect via number of matured fruits plant ${ }^{-1}(0.744)$, weight of fruits plant ${ }^{-1}(0.512)$ and days to $50 \%$ fruiting $(0.160)$ and resulted in positive effect $(0.814)$. Similarly the negative direct effect of number of fruits per cluster (0.208) was compensated by its indirect positive effect via number of matured fruits plant ${ }^{-1}(0.647)$, weight of fruits 
plant $^{-1}(0.442)$, days to $50 \%$ fruiting $(0.159)$ and number of fruit clusters plant ${ }^{-1}(0.102)$, which resulted in positive effect (0.218).

The positive direct effect of days to maturity on total fruit yield hectare ${ }^{-1}(0.030)$ was nullified by its indirect negative effects on number of matured fruits plant ${ }^{-1}$ ($0.528)$, weight of fruits plant ${ }^{-1}(-0.441)$, days to $50 \%$ fruiting $(-0.201)$ and number of fruit clusters plant ${ }^{-1}$ ($0.103)$ and resulted in negative effect $(-0.710)$. Similarly the positive direct effect of average single fruit weight plant $^{-1}(0.112)$ was nullified by its indirect negative effects via on number of matured fruits plant $^{-1}(-0.284)$ and resulted in negative effect $(-0.127)$. In line with this, Ghosh et al. (2010) reported that number of fruits per plant showed highest positive direct effect on fruit yield plant $^{-1}$ and number of flowers cluster ${ }^{-1}$ showed negative direct effect on fruit yield plant ${ }^{-1}$. Similarly Hidayatullah et al., 2008; Mehta and Asati, 2008; Tiwari and Upadhyay (2011) reported that weight of fruits per plant had the highest positive direct effect on fruit yield per plot.

Generally, the path analysis revealed that highest positive direct effect of number of fruits plant ${ }^{-1}$ and weight of fruits plant ${ }^{-1}$ on total fruit yield hectare ${ }^{-1}$ in conjunction with the highest positive indirect effect of fruit set percentage and number of fruits cluster ${ }^{-1}$ via number of fruits per plant and weight of fruits plant ${ }^{-1}$ on total fruit yield hectare ${ }^{-1}$ indicating these traits could be considered simultaneously as selection criterion for improving total fruit yield of tomato.

\section{Conclusion}

Of the studied 36 tomato genotypes CLN-2037-A (49.20 tons ha $^{-1}$ ) scored the highest fruit yield followed by CLN 5915-93-D4 (43.27 tons ha ${ }^{-1}$ ) and Miya (35.28 tons $\mathrm{ha}^{-1}$ ). Results of the path coefficient analysis showed that number of fruits plant ${ }^{-1}$ and weight of fruits plant $^{-1}$ had highest positive direct effect on fruit yield hectare ${ }^{-1}$. Hence direct selection based on those traits will be rewarding. Fruit set percentage and number of fruits per cluster had the highest positive indirect effect via number of fruits per plant and weight of fruits per plant. Therefore, the above traits could be considered as selection criterion in tomato improvement program.

\section{References}

[1] Dewey, D.R. and Lu,K.H, "A correlation and path coefficient analysis of components of crested wheat grass seed production," Agronomy Journal, 51, 515-518,1959.

[2] Ethiopian Agricultural Research Organization (EARO),An assessment of the agricultural production base, technological packages and innovation and intervention strategies for commercial farmers in Kafta- Humeraworeda of Tigray Regional State, Addis Ababa. 2002.

[3] FAOSTAT, Statistical Database of the Food and Agriculture of the United Nations. FAO, Rome, Italy. Available at http://faostat.fao.org.2011, Accessed on May 2011.
[4] FAOSTAT, Statistical Database of the Food and Agriculture of the United Nations. FAO, Rome, Italy. Available at http://faostat.fao.org.2012, Accessed on June 2014.

[5] Ghosh, K.P., Islam, A.K.M., Mian, M.A.K and Hossain, M.M, "Variability and character association in $\mathrm{F}_{2}$ segregating population of different commercial hybrids of tomato (Solanumlycopersicum L.),” J. Appl. Sci. Environ. Manage, 14 (2), 91-95, 2010.

[6] Hidayatullah, S.A., Jatoi, A.G. and Mahmood, T, "Path coefficient analysis of yield component in tomato (Lycopersiconesculentum)," Pak. J. Bot., 40 (2), 627-635, 2008.

[7] Islam, B.M.R., Ivy, N.A., Rasul, M.G. and Zakaria, M, "Character Association and path analysis of exotic tomato (Solanumlycopersicum L.) genotypes," Bagladesh J. Pl. Breed. Genet., 23 (1), 13-18, 2010.

[8] Jiregna, T.D, "Evaluation of agronomic performance and Lycopene variation in tomato (Lycopersiconesculentum Mill.) genotypes in Mizan, Southern Ethiopia." World Applied Sciences Journal, 27 (11), 1450-1454, 2013

[9] Lemma, D, Tomatoes Research Experience and Production Prospects, Ethiopian Agricultural Research Organization, Research Report No. 43, Addis Ababa. pp. 1-15. 2002.

[10] Mehta, M. and Asati, B.S, "Genetic relationship of growth and development traits with fruit yield in tomato (Lycopersiconesculentum Mill),"Karnataka J. Agric. Sci., 21 (1), 92-96, 2008.

[11] Meseret, D.R., Ali, M. and Kassahun, B, "Evaluation of tomato (Lycopersiconesculentum Mill.) genotypesfor yield and yield components," Journal of Plant Science and Biotechnology, Global science books, 2012.

[12] MoARD, Crop variety register: Animal and plant health regulatory directorate. Issue No. 12. Addis Ababa, Ethiopia. 145 p, 2009.

[13] Montogomery, D.C, Design and and Analysis of experiments ( $6^{\text {th }}$ ed.), John Willey and sons Inc., USA, pp 97-103, 2005.

[14] Muhammad, Y.S., Muhammed, A. and Qumer, I, "Augmented analysis for yield and some yield components in tomato (Lycopersiconesculentum Mill.),” Pak. J. Bot., 45 (1), 215-218, 2013.

[15] Naika, S., Jeude, J.V.L., Goffa, M., Hilmi, M. and Van Dam, B, Cultivation of tomato, $4^{\text {th }}$ edition, Agrodok- series No. 17, Agromisa Foundation and CTA, Wageningen. pp. 4-10.2005.

[16] Pradeepkumar, T., Bastian. D.M.J., Radhakrishnan, N.V. and Aipe, K.C, "Genetic variation in tomato for yield and resistance to bacterial wilt,” Journal of Tropical Agriculture, 39, 157-158, 2001.

[17] Reddy, B.R., Reddy, P.R., Reddy, S.D. and Begum, H, "Correlation and path analysis studies for yield and quality traits in tomato (Solanumlycopersicum L.)," IOSR Journal of Agriculture and veterinary science, volume 4, issue 4, pp 56-59, Jul-Aug. 2013.

[18] SAS Institute Inc, Statistical analysis Software version 9.2, Cary, NC: SAS Institute Inc. USA, 2008.

[19] Samonte, S.O., Wilson,L.T., and McMClig, A.M, "Path analysis of yield and yield related traits of fifteen diverse rice genotypes," Crop Science, 38: 1130-1136, 1998.

[20] Shashikanth, Basavaraj, N., Hosamani, R.M. and Patil, B.C, "Genetic variability in tomato (Solanumlycopersicon [Mill]. Wettsd.),” Karnataka J. Agric. Sci., 23 (3), 536-537, 2010.

[21] Syed, J.H., Khalid.M.K., Tarik, M., Hashim Laghari, M. and Masud, M, "Yield potential of some exotic and local tomato cultivars grown for summer production," Pakistan Journal of Biological Sciences, 4 (10), 1215-1216, 2001.

[22] Tanuja, B., Manish, K.S. and Thakur, K.S, "Genetic diversity and path analysis in tomato (Solanumlycopersicum L.)," Vegetable Science, 39 (2), 221-223, 2012.

[23] Tiwari, J.K. and Upadhyay, D, "Correlation and path-coefficient studies in tomato (Lycopersiconesculentum Mill.),"Research Journal of Agricultural Sciences, 2 (1), 63-68, 2011. 